\section{Forestry in British Honduras}

THE chief note of the annual report of the Forest Trust of British Honduras for the biennial period ending March 31, 1933 (Govt. Printer ; 1934) is one of marking time. The Department has now had ten years experience, but the increasing depression in the trade of the Colony necessitated economy during the period under review and the personnel was reduced to a skeleton service. The Forest Trust had early decided that further sylvicultural work, with its long lock-up of capital, was to be discontinued, and all reserves were placed on a 'care-and-maintenance' basis, an expression which will convey little to the forester possessing an acquaintance with the tropical forest. The energies of the Department are to be applied, therefore, to the furtherance of research work into the exploitation and marketing of the secondary timbers, with the view of taking prompt advantage of the recovery of world trade, when the present depression lifts. So far as it goes, this may be regarded as satisfactory; but the Department will have a long row to hoe before the position of half a decade or so ago is re-attained. The following extract from the report in connexion with taungya is of importance and should interest West African forest officers : "The practice of seedingup the annual corn-plantation with mahogany continues to give excellent results. Mahogany seed is dibbled in lines with the maize at 10 by 10 feet intervals, and the area is abandoned after the first crop has been harvested. The mahogany is then sufficiently established to compete with the weed growth, which very quickly closes the canopy. Overtopping of the mahogany by weed-growth is found to be beneficial in preventing shoot-borer (Hypsiphylla grandella) attack. 'Tending consists of removing vines. It is becoming very apparent that huamil (secondary growth) conditions are very favourable to the growth of mahogany, which grows well whilst its head is just under huamil canopy, and that heavy cleaning is not only undesirable but often disadvantageous in rendering the mahogany susceptible to the shootborer attack."

\section{Preservation of Newspaper Records}

NEWSPAPERS are an important class of historical records as they give a clear view of contemporary life and events. The newspaper files preserved in libraries give valuable reference records for historical purposes. Unfortunately, the paper on which they are printed is often made of crude ground wood fibre, which rapidly perishes, and the space they take up in libraries is excessive. In publication No. 145 of the U.S. Bureau of Standards (Washington : 5 cents), B. W. Scribner describes researches that have been made on methods of preserving newspapers. For retarding decay, the use of Japanese tissue paper has been found effective. Transparent cellulose acetate sheeting is also useful. Pending the development of more satisfactory materials and methods, an effort should be made to copy the most valuable of the older newspaper records on permanent paper by photostatic printing or photolithography.
Reproduction in miniature is the ideal method of reducing the space required. The technique of making miniature prints of newspaper records on transparent slides and projecting them in enlarged form for reading is making satisfactory progress. The life of the types of flexible film so far used is only about thirty to forty years. It is recommended that a joint effort be made at once by scientific and library organisations to find the most practical means for preserving newspaper records. Special stress should be laid on perfecting materials and methods of reproduction in miniature. The advisability of founding a central agency for supplying reproductions of newspapers and other records to libraries should also be considered.

\section{Rubber and Agriculture}

THE rapid development of the rubber industry has been one of the most notable industrial events of the present century. Between 1910 and 1933, the net amount of crude rubber exported from the principal producing countries increased from 94,000 tons to 851,000 tons per annum, while the world absorption of the manufactured product rose from 85,000 tons to 814,000 tons during the same period. Although the demand for motor tyres has been primarily responsible for this expansion, rubber has now found its place in practically every branch of industry. To illustrate the various ways in which it may be used on the farm, the Rubber Growers' Association (2-4 Idol Lane, Eastcheap, E.C.3) has issued a booklet entitled "Rubber and Agriculture". In outdoor equipment, not only can tyres of every description be supplied to suit everything from a tractor to a wheelbarrow, but also jointed tracks are suecessfully made. The inconvenience of the ordinary tipping device for unloading lorries is now avoidable by using a vehicle fitted with a rubber movable floor, which discharges on either side as desired. In the cow-shed and dairy, rubber stalls and flooring, rubber parts to the milking machines and rubber rims to the churns to reduce noise, are some of the uses to which this product can be put. In the farmhouse itself rubber is becoming increasingly popular; rubber floor coverings, brushes and even rubber upholstery now being practical propositions, while for the farmer and his family, rubber clothing of various types is a recognised part of their outfit.

\section{Small Sparks due to Static Electricity}

THE small sparks due to static electricity, similar to those sometimes observed when combing the hair or walking over a thick carpet, have caused fires which cost industry an appreciable amount, both in life and property. According to Science Service, of Washington, D.C., a study made by the Fire Protection Association shows that during the last six years 147 fires in the United States have been attributed to this cause. A frequent cause of sparking is the friction of an endless belt running over pulleys. In an atmosphere containing a certain amount of inflammable gases, this would be sufficient to cause an explosion which might result in a serious fire. 